\title{
НАГОРНА АНТОНІНА МАКСИМІВНА - ВИДАТНИЙ ЮВІЛЕЙ ТА 50-РІЧЧЯ НАУКОВОЇ ДІЯЛЬНОСТІ
}

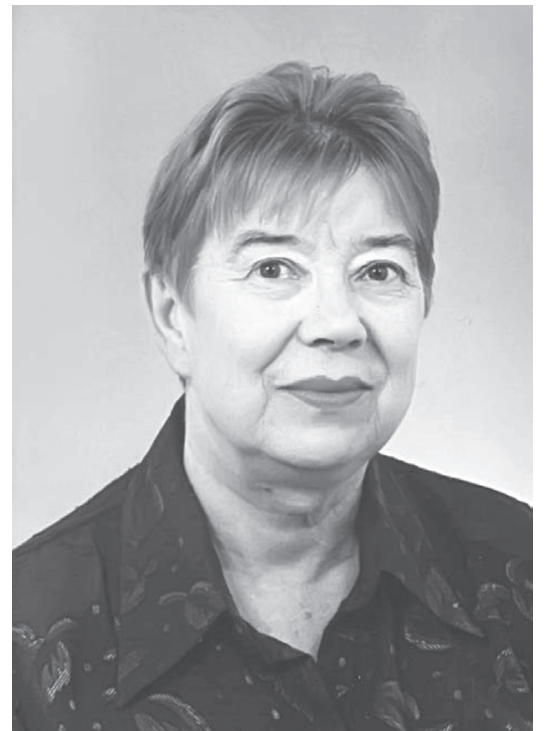

Стисло висвітлено основні біографрічні віхи й творчий доробок видатного вченого-гігієніста, доктора медичних наук, професора, заслуженого діяча науки й техніки України, члена-кореспондента Національної академії медичних наук України Антоніни Максимівни Нагорної.

21 січня 2020 р. виповнюється 80 років від дня народження Нагорної Антоніни Максимівни - видатного вченого, одного з фрундаторів української школи спеціалістів 3 питань профрілактичної медицини - гігієни праці, професійних захворювань і соціальної гігієни, завідуючої відділом епідеміологічних досліджень ДУ «Інститут медицини праці ім. Ю.І. Кундієва Національної академії медичних наук України», доктора медичних наук, професора, заслуженого діяча науки й техніки України, члена-кореспондента Національної академії медичних наук України, яка 50 років свого трудового життя присвятила медичній науці.

А.М. Нагорна народилася в м. Мурманськ (Росія) у сім"ї робітників. Після закінчення школи та медичного училища 5 років працювала медичною сестрою. У 1962 р. поступила на лікувальний фракультет Одеського медичного інституту, далі була переведена у Київський медичний інститут імені О.О. Богомольця, який успішно закінчила в 1968 р. за спеціальністю «лікувальна справа».
Під час роботи цеховим ординатором медико-санітарної частини Дарницького шовкового комбінату її зацікавили проблеми професійних захворювань, що дало поштовх у 1970 р. перейти на роботу до Київського інституту гігієни праці та професійних захворювань (нині Інститут медицини праці імені Ю.І. Кундієва НАМН України) і розпочати науково-дослідну роботу гігієнічного спрямування. На посадах спочатку молодшого наукового співробітника, далі, 3 1979 р., старшого наукового співробітника Антоніна Максимівна вивчала проблеми здоров'я різних професійних груп, медичних протипоказань до прийому на роботу, гігієнічної регламентації розумового та фрізичного навантаження.

Сорера наукових інтересів А.М. Нагорної і зараз охоплює здоров'я населення різних профресійних та соціальних груп, медико-демографрічні процеси в суспільстві, показники громадського здоров'я, питання організації та управління охороною здоров'я на різних її рівнях.

У своїй науковій роботі значну роль приділяє професійним захворюванням інфекційного ґенезу. Під її керівництвом виконувалася науково-дослідна робота «Оцінка професійного ризику та впровадження в Україні системи профрілактики ВІЛ-інфекції/СНІДу на робочих місцях, за стандартами Міжнародної організації праці (МОП)» та дослідження щодо наукового обґрунтування епідеміологічного нагляду та профілактики захворюваності на професійний туберкульоз у працюючих в Україні.

Результати наукових досліджень знайшли своє відображення у багатьох наукових статтях, а саме: «Стратегія розвитку профрілактики в охороні здоров'я в Україні», «Розробка інструменту для оцінки ризику професійного інфрікування ВІЛ на робочому місці», «Оцінка адекватності забезпечення профрілактики ВІЛ-інфрікування на робочому місці в галузі охорони здоров'я України, відповідно до рекомендації МОП та ВООЗ», «Оцінка професійних ризиків ВІЛінсрікування працівників лікувально-просрілактичних закладів хірургічного та фртизіатричного профрілів», «Захворюваність медичних працівників на професійний туберкульоз», «Захворюваність на професійний туберкульоз в Україні (1993-2008рр.)», «Стан захворюваності на коніотуберкульоз серед робітників в Україні (19932008 рр.)», «Захворюваність на туберкульоз професійного ґенезу в Україні в 2013-2017 рр.» та в монографріях «До- 
слідження стигми і дискримінації, пов'язаної з ВІЛ-статусом, серед медичних працівників і по відношенню до пацієнтів в Україні», «Профресійні інфекційні хвороби», «Профресія і туберкульоз. Український вимір».

Особлива її увага приділялась вивченню захворюваності на професійний туберкульоз серед медичних працівників, працівників добувної, переробної промисловості, машинобудівництва тощо.

Антоніна Максимівна $є$ автором понад 650 наукових праць, серед яких 46 монографій, книг і навчальних посібників, має наукову школу з підготовки кандидатів і докторів медичних наук. За це вона була нагороджена відзнакою (золота медаль) Національної академії наук України «За підготовку наукової зміни».

Інфрормація про Нагорну А.М. найшла своє відображення у біографрічному щорічнику «Імена України» (1999), у біографрічному енциклопедичному словнику «Жінки України» (2001), у матеріалах Національної академії медичних наук України, присвячених 20- та 25-річчю установи (2013, 2018), у наукових журналах тощо.

Професор Нагорна А.М. бере активну участь у житті суспільства, наукових співтовариств та асоціацій, періодичних наукових видань, користується повагою та авторитетом серед співробітників і колег різних галузей медицини. Своєю творчою енергією спонукає своїх учнів і колег до нових наукових звершень. щиро вітаємо Антоніну Максимівну з ювілеєм. Бажаємо міцного здоров'я, благополуччя, подальшої творчої наснаги і радості від спілкування з людьми, небайдужими до науки і життя.

Колектив ДУ «Інститут медицини праці імені Ю.І. Кундієва НАМН України»,

ГО «Асоціація науковців і лікарів з профресійної патології та гігієни праці України»

\section{NAHORNA ANTONINA MAKSYMIVNA \\ - AN EXCELLENT JUBILEE AND 50TH ANNIVERSARY OF SCIENTIFIC ACTIVITIES}

SUMMARY. The main biographical milestones and creative achievements of the prominent scientisthygienist, Doctor of Medical Sciences, Professor, honored worker of science and technology of Ukraine, member of the correspondent of the National Academy of Medical Sciences of Ukraine Antonina Maksymivna Nahorna are briefly covered.

Конфрлікту інтересів немає.

The authors declare that they have no conflicts of interest.

Отримано 24.12.2019 р. 